\title{
Ethnobotany of People around the Dolok Sibual-Buali Nature Reserve Area, North Sumatra, Indonesia
}

\author{
Herwint SiMBOLON Center for Research and Development in Biology, The Indonesian Institute of \\ Sciences, Jl. Juanda 22, Bogor 16122, INDONESIA
}

\begin{abstract}
The ethnobotany, particularly the relationship between people and forests, of the Dolok Sibual-buali Nature Reserve Area was studied. The villages around the Nature Reserve are traditionally established away from forests and agricultural areas and are inhabited by the Batak ethnic group. Within the village, houses are built closed to each other without home-garden. The village is usually surrounded by sawah (paddy-fields), ladangs, and forests at the outer edge. Five out of 15 villages around the Dolok Sibual-buali Nature Reserve are remote and far away from the center of community activities. The magnitude of dependency on the forest products of the people in the remote villages is relatively greater than do the people in the other villages. The people in the remote villages utilize the Nature Reserve as resources for traditional medicine, home industry, and daily needs such as food, including resources of traditional food industry, fire woods and construction materials.
\end{abstract}

Key words: ethnobotany / nature reserve / medicinal plants / home industry / fire woods / tropical forest.

The dependency of people on their natural environmental is determined by geographical location where they live, accessibility and awareness of people regarding innovation. The people who live in remote and isolated village depend largely on the products that they cultivate and other commodities that they gather from surrounding vegetation.

There are many villages around the Dolok Sibual-buali Nature Reserve Area, North Sumatra, and some are geographically remote and far away from the center of community activities. The people around the Nature Reserve are farmers, and most people in the remote villages are dependent for their construction materials, utensil, medicinal plants, and other commodities on local forest product.

This paper intends to study ethnobotany of Batak Tapanuli Selatan people, particularly the relationship between the people and the forest of the Dolok Sibual-buali Nature Reserve Area.

\section{STUDY SITES}

The study area was comprised of the forests within the Dolok Sibual-buali Nature Reserve and the villages surrounding the reserve. Administratively, the study area is located in the Tapanuli Selatan Regency, North Sumatra Province, Indonesia (Fig. 1).

The Dolok Sibual-buali Nature Reserve covers an area of about 5,000 ha, and the altitude ranging between 1,100 to $1,819 \mathrm{~m}$ above sea level. It is the southern part of the Batak Tumor (Bemmelen, 1949) within the Bukit Barisan Mountain Range. Its forest is still intact, 


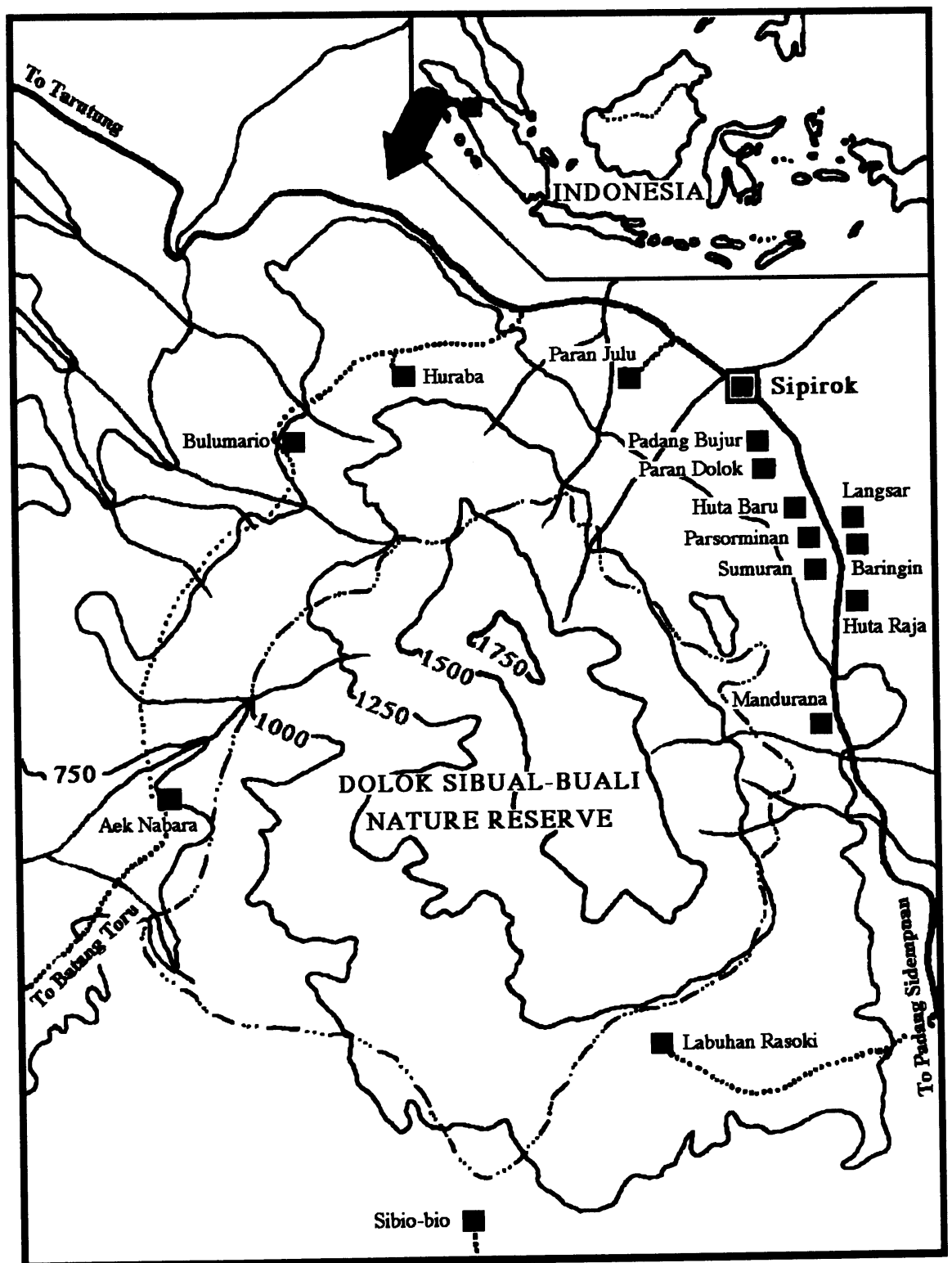

Fig. 1. Map of study sites.

characterized with the occurrence of large diameter of primary tree species, and no human disturbance (see The Indonesian Institute of Sciences, 1993). Below the altitude of 1,100 m the area can be classified into three forms of land use, i.e. secondary forest which is traditionally used by the people, ladang where people practice upland agriculture, and sawah (paddy-fields). Trees in the secondary forest are periodically cut and used for fire- wood. In other parts, there is tanah adat land (i.e. belongs to ethnic group) for ladang that afterward was abandoned and fallowed to become secondary forests.

The study was conducted in 15 villages within the foot-hills of the reserve. The villages itself administratively belongs to three districts (kecamatan). Those villages are: 
1. Sipirok District, includes the following villages:
1.1. Baringin
1. 8. Mandurana
1.2. Bulumario
1. 9. Padang Bujur
1.3. Huraba
1.10. Paran Dolok
1.4. Huta Baru
1.11. Paran Julu
1.5. Huta Raja
1.12. Parsorminan
1.6. Labuhan Rasoki
1.13. Sumuran
1.7. Langsar

2. East Padang Sidempuan District, only includes one village:

\subsection{Sibio-bio}

3. Batang Toru District, only includes one village:

\subsection{Aek Nabara}

These villages are geographically distributed in three centers of economic activities. Firstly along the main road of Trans Sumatra between Padang Sidempuan and Tarutung, where/Sipirok is the center; secondly along the main road from Padang Sidempuan to Sibolga where Batang Toru is the center; and thirdly, Padang Sidempuan as the main capital of South Tapanuli Regency. Geographically, five villages are located relatively away from those centers, i.e. Bulumario, Huraba, Labuhan Rasoki, Sibio-bio, and Aek Nabara.

These villages are inhabited by the Batak ethnic group, but specifically by sub- ethnic Batak Tapanuli Selatan (South Tapanuli), whose people are distinct from the other Batak subethnics such as: Batak Toba, Batak Angkola, Batak Karo and Batak Simalungun. Despite that these ethnic groups come from the same Batak forebears, the Batak Tapanuli Selatan is culturally different. The sub-ethnic Batak Tapanuli Selatan has been culturally influenced by the people of Padang ethnic group from the west Sumatra Province.

\section{METHODS}

Ethnobotanical information concerning relationships between people and forests of the Dolok Sibual-buali Nature Reserve was obtained by interviewing key- and primary informants, conducted in May-June 1993. The ethnobotanical information includes how the villagers use the plants from surrounding vegetation in daily life, such as plants for construction, utensils, medicines and home industry materials.

Key-informants within villages were interviewed to get general views concerning ethnobotanical custom of the village. The key-informants, generally, are highly respected and of high status within the village, as well as knowledgeable of custom or tradition of the village. Those key-informants are village leaders, religion leaders, kings of the custom (raja adat), highly educated people, and government officers. The ethnobotanical information obtained from the key-informants were, then, confirmed by villagers as primary source and where the ethnobotanical activities were took place.

Based on the information obtained from both sources, the ethnobotanical activities were described, and the vernacular names of plants and their usage in daily life were noted. For botanical1confirmatin, all plants used for such purposes were directly collected in the field and identified taxonomically at the Herbarium Bogoriense, Center for Research and Development in Biology, The Indonesian Institute of Sciences, Bogor. 
Table 1. Utilization of plants for traditional medicine of Batak live around Dolok Sibualbuali Nature Reserve.

\begin{tabular}{|c|c|c|c|c|}
\hline Family & $\begin{array}{c}\text { Vernacular } \\
\text { name }\end{array}$ & $\begin{array}{l}\text { Part of } \\
\text { plant }\end{array}$ & Usage & $\begin{array}{l}\text { Type of } \\
\text { Disease }\end{array}$ \\
\hline Anac. & Mangifera indica & Leaves & $\begin{array}{l}\text { Leaves, mixed with } \\
\text { Sibodak,are treated } \\
\text { as tea, and used as } \\
\text { mouth-washing }\end{array}$ & Tooth ache \\
\hline Anac. 1 & Mangifera odorata & Young leaves & $\begin{array}{l}\text { Young leaves are } \\
\text { dried and ground, } \\
\text { treated as tea }\end{array}$ & $\begin{array}{l}\text { Stomach } \\
\text { ache }\end{array}$ \\
\hline Bisch. & Bischofia javanica & Young leaves & $\begin{array}{l}\text { Young leaves are } \\
\text { treated as tea }\end{array}$ & $\begin{array}{r}\text { Stomach } \\
\text { ache }\end{array}$ \\
\hline Comp. & $\begin{array}{r}\text { Erechtites hieracifolia Duhut haba- } \\
\text { haba }\end{array}$ & Leaves & $\begin{array}{l}\text { Leaves are ground and } \\
\text { stuck on the wounds }\end{array}$ & $\begin{array}{r}\text { Curing the } \\
\text { wounds }\end{array}$ \\
\hline Comp. & $\begin{array}{l}\text { Sirompas } \\
\text { para }\end{array}$ & Leaves & $\begin{array}{l}\text { Leaves are ground } \\
\text { and stuck on the wound } \\
\text { or scratchy skin }\end{array}$ & $\begin{array}{l}\text { Scratchy } \\
\text { ds skin }\end{array}$ \\
\hline Euph. & $\begin{array}{r}\text { Euphorbia heterophylla Siburantak } \\
\text { or Kastroli }\end{array}$ & Leaves & $\begin{array}{l}\text { Leaves are put into } \\
\text { boiled water and the } \\
\text { liquid and leaves are } \\
\text { taken }\end{array}$ & Dioreticum \\
\hline Euph. & Homalanthus populnea Andulpak & Nuts & $\begin{array}{l}\text { Nuts, mixed with } \\
\text { 'tawas', are fried and } \\
\text { ground. Powder is used } \\
\text { for scratchy skin }\end{array}$ & $\begin{array}{l}\text { Scratchy } \\
\text { skin }\end{array}$ \\
\hline Gram. & Bambusa sp. & Leaves & $\begin{array}{l}\text { Mixed with Hulim } \\
\text { leaves, are boiled in wat } \\
\text { and the liquid is used } f \\
\text { washing the body }\end{array}$ & $\begin{array}{l}\text { Skin disease } \\
\text { ter } \\
\text { for }\end{array}$ \\
\hline Gram. & Setaria palmifolia & Leaves & $\begin{array}{l}\text { Leaves are put into } \\
\text { boiled water }\end{array}$ & $\begin{array}{l}\text { Body } \\
\text { washing }\end{array}$ \\
\hline Labi. & Pogostemon heyneanus Nilam & Leaves & $\begin{array}{l}\text { Leaves are ground, and } \\
\text { stuck on the wounds }\end{array}$ & $\begin{array}{l}\text { Curing } \\
\text { wound }\end{array}$ \\
\hline Legu. & Andor bio-bio & Leaves & $\begin{array}{l}\text { Leaves are ground, } \\
\text { and stuck on the wounds }\end{array}$ & $\begin{array}{l}\text { Curing } \\
\text { ls wound }\end{array}$ \\
\hline Legu. & Pterocarpus indicus & Latex & $\begin{array}{l}\text { Latex is greased to } \\
\text { the gum }\end{array}$ & $\begin{array}{l}\text { Gum } \\
\text { disease }\end{array}$ \\
\hline Lili. & Cordyline fruticosa & Young leaves & $\begin{array}{l}\text { Young leaves are } \\
\text { treated as tea }\end{array}$ & $\begin{array}{l}\text { Stomach } \\
\text { ache }\end{array}$ \\
\hline Lora. & Loranthus sp. & Leaves & $\begin{array}{l}\text { Leaves are treated } \\
\text { as tea }\end{array}$ & $\begin{array}{l}\text { Back- } \\
\text { illness }\end{array}$ \\
\hline Mela. & Melastoma affine & Leaves & $\begin{array}{l}\text { Leaves are treated } \\
\text { as tea }\end{array}$ & $\begin{array}{r}\text { Stomach } \\
\text { ache }\end{array}$ \\
\hline Meli. & Lansium domesticum Lansat & Leaves & $\begin{array}{l}\text { Leaves are treated } \\
\text { as tea }\end{array}$ & $\begin{array}{l}\text { Back- } \\
\text { illness }\end{array}$ \\
\hline Meni. & $\begin{array}{c}\text { Pericampylus glaucus } \begin{array}{c}\text { Andor } \\
\text { baliang }\end{array} \\
\text { balis }\end{array}$ & Leaves & $\begin{array}{l}\text { Leaves are boiled } \\
\text { in the water, and the } \\
\text { liquid is taken for diare }\end{array}$ & Diare \\
\hline Mora. & Artocarpus heterophyllus Sibodak & Leaves & $\begin{array}{l}\text { Leaves, mixed with } \\
\text { mangga, are treated as } \\
\text { tea, and used as mouth } \\
\text { washing }\end{array}$ & $\begin{array}{l}\text { Tooth ache } \\
\text { th- }\end{array}$ \\
\hline Myrt. & Psidium guajava & Young leaves & $\begin{array}{l}\text { Young leaves are } \\
\text { treated as tea }\end{array}$ & $\begin{array}{r}\text { Stomach } \\
\text { ache }\end{array}$ \\
\hline
\end{tabular}




\begin{tabular}{|c|c|c|c|c|c|}
\hline Olac. & Scorodocarpus bornee & ensis Hulim & Leaves & $\begin{array}{l}\text { Mixed with Bulu } \\
\text { leaves, are boild in } \\
\text { water and the liquid } \\
\text { is used for washing the b }\end{array}$ & Skin disease \\
\hline Pipe. & Piper bettle & Burangir & Leaves & $\begin{array}{l}\text { Leaves are boiled } \\
\text { in water }\end{array}$ & $\begin{array}{r}\text { Stomach } \\
\text { ache }\end{array}$ \\
\hline Pipe. & Piper ribesioides & $\begin{array}{l}\text { Sinyar-sinyar } \\
\text { or Andaliman }\end{array}$ & Leaves & $\begin{array}{l}\text { Leaves are boiled in } \\
\text { water, and the liquid } \\
\text { is taken }\end{array}$ & $\begin{array}{r}\text { Stomach } \\
\text { ache }\end{array}$ \\
\hline Rosa. & Rubus rosaefolius & Sanggirgir & Leaves & & $\begin{array}{r}\text { Stomach } \\
\text { ache }\end{array}$ \\
\hline Sola. & Physalis peruviana & Pultak-pultak & All & $\begin{array}{l}\text { Succulent plants are } \\
\text { cut intopieces, dried, } \\
\text { and boiled. The liquid } \\
\text { is taken }\end{array}$ & $\begin{array}{l}\text { Stomach } \\
\text { ache }\end{array}$ \\
\hline Umbe. & Centella asiatica & Ampapaga & Leaves & $\begin{array}{l}\text { Treated as tea, the } \\
\text { plants are taken as } \\
\text { vegetable }\end{array}$ & $\begin{array}{r}\text { Stomach } \\
\text { ache }\end{array}$ \\
\hline Verb. & \multicolumn{2}{|c|}{ Clerodendrum serratum Pindotosik } & Leaves & $\begin{array}{l}\text { Leaves are boiled } \\
\text { in water, and liquid } \\
\text { is taken. Also, pamode } \\
\text { (leaves are stuck on the } \\
\text { stomach) }\end{array}$ & $\begin{array}{l}\text { Stomach } \\
\text { ache } \\
\text { el } \\
\text { e }\end{array}$ \\
\hline
\end{tabular}

\section{RESULTS}

\section{People Understanding of Environment}

The Batak people are traditionally establishing a "huta" (kampong, a small village) where they settle away from forests and agricultural areas. Within a huta, houses are built closed to each other without home-garden, and without trees planted surrounding the huta. Huta is usually surrounded by sawah (paddy-fields), ladangs, and forests at the outer edge.

Today the people surrounding the Dolok Sibual-buali Nature Reserve do not seem to have any traditional concepts of understanding the environment, particularly those related to nature conservation. This is reflected by the existing traditional rules which do not have correlation with natural environment. The existing traditional rules mostly deal with their kin relationship between and within families, instead of their lives with natural environment. The study found that the people understanding on their surrounding environment was a result of nature conservation promotion done by local agency, i.e. Forest Protection and Nature Conservation Agency. Such promotion has provided the people with the laws of nature conservation endorsed by the government, such as the prohibition of forest exploitation within the Nature Reserve, while such an understanding was not endorsed by their traditional rules.

\section{Agricultural and Plant Utilization}

The people surrounding the reserve did not fully depend on forest product for their lives. They are generally farmer practicing 'persawahan', i.e. rice-field farming during rainy season and chilly pepper farming during dry seasons, and planting coffee (Coffea spp.), cinnamon (Cinnamomum burmannii), rubber (Hevea brasiliensis), and salak (Salacca edulis) in their ladangs. The agricultural areas are commonly established out-side the Nature Reserve, so they do not damage forest ecosystem.

Apart from agricultural practices, some people do utilize plant resources within the forests 
or the foot-hills of the Dolok Sibual-buali Nature Reserve. This utilization can be generally categorized into four groups, namely use for traditional medicine, home industry, daily needs, and uses for traditional food industry.

\section{Plants As Traditional Medicine Resources}

Since such villages as Bulumario, Huraba, Labuhan Rasoki, Sibio-bio, and Aek Nabara are geographically remote, the introduction of modern health care is very limited. -

Although some other villages do not either have any health center facility, the communities of these villages can easily reach the health centers of other villages. These people, also those living near the foot-hills, commonly utilize plants as the source of medicine. This has made the magnitude of dependency of these people on wild plants from the forest greater than others.

Although the magnitude of dependency of people on wild plants varies within villages, almost all communities utilize the same plant species for the same treatment of illness. This is probably due to the fact that the people in these communities come from the same ethnic group and utilize the wild plants from the same geographical areas.

From field data collection and voucher specimens, the people surrounding the Nature Reserve use the following plants species for traditional medicines (see Table 1.)

\section{Plants As Resources of Home Industry}

There are three utensils considered as a result of home industry. These utensils utilize plants as raw materials.

a. Brooms

The broom uses raw materials of 'ijuk' (black sugar-palm, Arenga pinnata, fiber) and the wood of any species of plants found in the secondary forest, and any species of rattan (Calamus spp., Korthalsia sp., and Daemonorops sp.) are used for string to tighten it.These rattans are found in primary forests inside the Nature Reserve.

The broom makers or crafters are found in almost all villages, but they do not produce the brooms in a large number. Instead, they produce these crafts for personal use or trade them to other people within the village in a small scale. This broom production is the main occupation of some people in such villages as Huta Baru (Sipirok District) and Sibio-bio (East Padang Sidempuan District). The people in Aek Nabara (Batang Toru District) do not only produce brooms, but also trade the 'ijuk' as raw materials with people from other villages.

b. Tampi or Nyiru (Winnows)

It is made of bamboos (Bambusa spp.) found in the secondary forest, and rattans. Most people produce tampi for their own use, except two families in Sibio-bio village who produce it for their main income.

c. Baskets and 'tangguk' (small fish net)

They are made of bamboos or 'bomban' (Marantha sp.) found in the secondary forest. Most people produce these materials for their own use, except some people in Sibio-bio village who produce them as their main occupation.

\section{Plants As Resources in Daily Life}

Daily, people in all villages utilize woods for fuel and occasionally for house- building materials. Resources of fire-woods are usually any species of trees (Table 2) found in secondary forest, with the diameters between 7 and $15 \mathrm{~cm}$. Each family usually employs one of its member to collect fire-woods for two months, and collected fire-woods will serve the 
family for a year long. Fire-wood, which is daily collected, can be as much as 15 trunks of $1.5 \mathrm{~m}$ long. Fire-wood collection is usually carried out when there is no agricultural activities such as ploughing, planting, or harvesting rice in sawah or ladangs.

Materials for building house are more specific than those for fire-wood. People used to utilize Sampinur tali (Dacrydium junghuhnii), Sampinur bunga (Podocarpus imbricatus) and Anturmangan (Casuarina sumatrana) for housing. These species are now no longer found within the forest of 'tanah adat'. These species are, however, still found in the Nature Reserve area at certain elevations (The Indonesian Institute of Sciences, 1993). The people, instead, utilize the other species of trees for house building materials as listed in Table 3.

People who still utilize trees from surrounding the villages are those from Bulumario, Huraba, Labuhan Rasoki, Sibio-bio and Aek Nabara. On average, the people in each village build a house per year. People in other villages commonly obtain such materials in the shops where the materials are transported from other areas.

In the remote villages, people gather young leaves or fruits of wild plants for vegetable from the forest or the foot-hills of the Dolok Sibual-buali Nature Reserve. Species for vegetables namely genjer (Limnocharis flava), pahu (Filices sp.), poga (Endospermum diadenum), ranti (Solanum denticulatum), rimbang (Solanum indicum, fruits), sitopu (Claoxylon indicum), tubis (Bambusa sp., shoot) and ukam (Musa sp., flower bud).

\section{Sugar-palms As Resources of Traditional Food Industry}

Sugar-palm (Arenga pinnata) plays an important role in the daily lives of people in all villages. Sugar-palm provides people with its 'ijuk', and palm-sap ('nira'). Nira is the main source of brown sugar. Tapped palms are commonly grown in 'tanah adat' and sometimes in the Nature Reserve. The people do not tap the nira from palms before the third inflorescences emerge. The first and second inflorescences are usually left to maturity for seed regeneration. Beside, people believe that nira production from the first and second inflorescens is lower than that in the following inflorescens.

Each family usually taps 4-6 trees sugar-palm daily. Four or five palms can produce 20 liters of nira, from which $2.5-3.0 \mathrm{kgs}$ of brown-sugar can be obtained after processing. Firewood is needed for processing. Each palm can be tapped for as long as 2 to 3 months.

\section{DISCUSSION}

The Batak people do not have traditional concept of understanding environment in their 'adat' (custom). This is in contrast with the 'adat' of other ethnic groups such as Dani tribes in Baliem, Irian Jaya (Purwanto \& Walujo, 1992), or Mentawai tribes in Siberut Isl., West Sumatra (Ave \& Sunio, 1990). These tribes have their traditional relationship with surrounding environment, which is reflected in their way of life or 'adat'.

Activities of the people who live surrounding the Dolok Sibual-buali Nature Reserve do not have negative impact to the existence of the reserve. This might be due to such factors as: 1. people were generally farmers, and not dependent on forest products. 2. Secondary forests surrounding the Nature Reserve played as buffer zone which supply the people need for woods and food, and 3. Public awareness about the prohibition of natural resource exploitation within the Nature Reserve was apparently high.

The number of species for medicinal plant used by people around the Dolok Sibual- buali 
Table 2. Fire-woods species used by Batak live around Dolok Sibual-buali Nature Reserve.

\begin{tabular}{lll}
\hline Family & Species & Vernacular name \\
\hline Actinidiac. & Saurauia sp. & Pirdot eme \\
Euphorb. & Glochidion obscurum & Goring-goring \\
& Hevea brasiliensis & Rambong \\
& Macaranga javanica & Simartulan \\
& Macaranga sp. & Sitarak \\
& Sapium baccatum & Andulpak \\
Fagac. & Castanopsis spp. & Hoteng \\
& Lithocarpus spp. & Hoteng \\
& Quercus spp. & Hoteng \\
Laurac. & Litsea sp. & Modang \\
Legum. & Erythrina sp. & Dap-dap \\
Melastom. & Melastoma affine & Sanduduk \\
& Pternandra coerulescens & Siak-siak \\
Meliac. & Toona sureni & Badupara \\
Morac. & Ficus rumphii & Jabijabi \\
& Ficus variegata & Tanki gatal \\
& Ficus sp. & Haruaya \\
Myrtac. & Eugenia spp. & Haundolok \\
& Tristania sp. & Inggolan \\
Palmae & Arenga pinnata & Bargot. \\
Rhizophorac. & Carallia brachiata & Tinggiran \\
Rubiac. & Neonauclea calycina & Algit \\
Symploc. & Symplocos spp. & Sihodung \\
Theac. & Eurya accuminata & Tambisiki \\
Theac. & Schima wallichii & Simartolu \\
\hline & &
\end{tabular}

Table 3. Species of tree used as materials of house building by Batak live around Dolok Sibual-buali Nature Reserve.

\begin{tabular}{lll}
\hline Family & Species & Vernacular name \\
\hline Alanginac. & Alangium kurzii & Hole tanduk \\
Anacardiac. & Buchanania auriculata & Modang sangkotan \\
Apocynac. & Alstonia scholaris & Goti \\
Dipterocarp. & Shorea ssp. & Maranti \\
Fagac. & Castanopsis spp. & Hoteng \\
& Lithocarpus spp. & Hoteng \\
& Quercus sp. & Simarbawang \\
Laurac. & Actinodaphne glomerata & Modang \\
& Nothaphoebe umbellifora & Modang katunohan \\
& Phoebe cuneata & Modang tanduk \\
Meliac. & Aglaia argentea & Bayur \\
& Toona sureni & Badupara \\
Morac. & Morus macroura & Hole tanduk \\
Theac. & Laplacea sp. & Api-api \\
\hline
\end{tabular}


Nature Reserve is relatively lower ( 28 species belong to 20 family) than that of in other areas of Sumatra such as Bengkulu (Uji et al., 1992), Kubu (Agoes et al., 1975), and Mentawai, Siberut Isl. (Ave \& Sunio, 1990). The small number of species used for medicinal plant in the research area may be due to the limited number of plant species in the high altitude, and introduction of modern medicines. Most people in the villages around the Nature Reserve can easily reach the health centers in the main capital of districts. At present, the people prefer using modern medicines rather than traditional ones. As a result, their knowledge on the species and usage of traditional medicine plant is decreasing.

Plant species used for medicine in the study areas are common and also reported by others. These medicinal plants are used in other areas of Indonesia (Heyne, 1950), in Malay Peninsula (Burkill, 1935) and in the Philippines (Quisumbing, 1951). These medicinal plants are widely distributed in southeast Asia. However, the leaves of Mangifera odorata which has edible fruits, are not reported either by Heyne (1950), Burkill (1935) or Quisumbing (1951) as a medicinal plant. People around the Nature Reserve use the $M$. odorata leaves as a traditional medicine for stomachache. Another example, bamboo's leaves are boiled with other species for skin disease, however, in the Philippines, the Bambusa spinosa leaves are used as an emmenagogue and anthelmintic (Quisumbing, 1951). For other species, different plant parts are used for different types of illness with different ways of preparation. These facts indicate that plant species and plant parts for medicine are used differently from place to place. As shown in Table 1, within a plant species, the leaves are the most usable part than the other parts in the study areas. These leaves are prepared mostly for the stomachache cure.

Limited numbers of crafters in some villages, especially Sibio-bio village, have occupation that depends on forest products such as rattans. The increasing number of crafters and their production may impose a serious threat to the existence of rattan species, since they can only be obtained in the Nature Reserve. The activities of broom-makers in Huta Baru village and 'ijuk' gatherers in Aek Nabara village did not seem to threaten the Nature Reserve, since 'ijuk' could be obtained without cutting the palms. Brown-sugar production also did not impose any threat to the Nature Reserve, because the trees could be found outside the reserve. In addition, traditionally, people do not tap the first and second flowers, and this sustains the palm regeneration.

Almost all villagers collect fire-wood from the surrounding areas of the Nature Reserve. It might impose a serious threat in the future. Another threat might come from the collection of house-building materials which is done by the people from Huraba, Bulumario, Labuhan Rasoki, Batang Toru and Sibio-bio villages. Due to the closed location of these villages to the Nature Reserve, the people relatively more depend on the Nature Reserve than those of other distant villages.

ACKNOWLEDGEMENT I would like to express my sincere gratitude to all members of the Dolok Sibual- buali Nature Reserve team for their cooperation during the field surveys, and to Drs. Asep A. Adhikerana, Eko B. Walujo and H. Soedjito for their critical reading of the draft. The research was sponsored by PERTAMINA-UNOCAL North Sumatra Geothermal Ltd.

\section{REFERENCES}

Agoes, A., Chadir, J. \& Sumadilaga, R. S. 1975. Obat-obat asli suku Kubu. Proceedings of 
Symposium on Medicinal Plant Research, Bogor, pp. 22-33.

Ave, W. \& Sunio, S. 1990. Medicinal Plants of Siberut. A World Wide Fund for Nature Report.

Bemmelen, R.W. van. 1949. The Geology of Indonesia. Den Haag.

Burkill, I.H. 1935. A Dictionary of the Economic Products of the Malay Peninsula. London, 2 volumes.

Heyne, K. 1950. De Nuttige Planten van Indonesie. Bandung, 2 volumes.

Purwanto, Y. \& Walujo, E. B. 1992. Etnobotani suku Dani di lembah Baliem, Irian Jaya: Suatu telaah tentang pengetahuan dan pemanfaatan sumber daya alam tumbuhan. Proceedings of Seminar dan Lokakarya Nasional Etnobotani, Cisarua, Bogor: pp. 132-148.

Quisumbing, E. 1951. Medicinal Plants of the Philippines. Manila.

The Indonesian Institute of Sciences. 1993. Environmental Baseline Study of the Dolok Sibual-buali Nature Reserve Area. Final Report. PERTAMINA-UNOCAL North Sumatra Geothermal Ltd.

Uji, T., Wiriadinata, H., Kitagawa, I. \& Shibuya, H. 1992. Penelitian pemanfaatan tumbuhan sebagai obat tradisional di Rejang Lebong, Bengkulu, Indonesia. Proceedings of Seminar on Ethnobotany, Bogor: pp. 60-66.

Received April 14, 1994

Accepted Aug. 1, 1994

\section{Herwint SIMBOLONインドネシア北スマトラ，ドロクシブァル-ブアリ自然保護地 域周辺の住民の植物利用}

地域住民と植物利用，特に森林との関係についてドロクシブアルーブアリ自然保護地域において 調査を行った。この自然保護地域を取り巻く村落はバタック族が住み，森林を伐採し，農耕地を 作る伝統的なやり方で作られたものである。村落内では，住居は密接して建てられ，家庭菜園 (キッチンガーデン) は付属していない。村落の周囲は水田, 畑地あるいは森林が取り囲んでい る。ドロクシブアル-ブアリ自然保護地域周辺の15の村落のうちの5つは，中心地域からはずれ， 孤立して存在する。これらの隔離された村落では森林生産物が占める生活上の重要性は相対的に 高かった。それらの村落では, 自然保護地域から得られる植物資源が，各種の民間薬（表 1 , 利 用されている種類数は比較的少ない)，ほうき，箕，かごや魚網などの家内工業的な生産の原材 料, 日々の生活資材である食料や伝統的な食品生産（特にサトゥヤシからの黒砂糖の生産）, 薪 炭材（表 2)，あるいは建築材（表 3）などにとって重要であった。 